\title{
Diversity of scale insects (Hemiptera: Coccomorpha) attacking citrus trees in Machakos, Makueni, Kilifi and Kwale Counties, Kenya
}

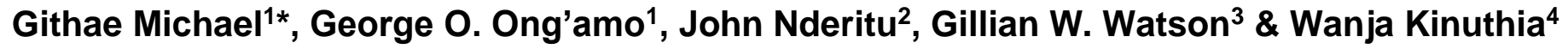

\author{
${ }^{1}$ School of Biological Sciences, University of Nairobi, 30197, 00100 Nairobi, Kenya. \\ ${ }^{2}$ Department of Crop Science and Protection, University of Nairobi, 30197, 00100 Nairobi, Kenya. \\ ${ }^{3}$ Department of Life Sciences, the National History Museum, London, SW7 5BD, U.K. \\ ${ }^{4}$ Invertebrate Zoology Section, National Museums of Kenya, Nairobi, Kenya.
}

${ }^{*}$ Corresponding author. Email: michaelmathenge7@gmail.com

Copyright @ 2021 Githae et al. This article remains permanently open access under the terms of the Creative Commons Attribution License 4.0, which permits unrestricted use, distribution, and reproduction in any medium, provided the original work is properly cited.

Received 26th April, 2021; Accepted 15th May, 2021

\begin{abstract}
Citrus farming is a major source of revenue for large and small-scale farmers in Kenya. Citrus production is confronted with threats from pests and diseases. Surveys of citrus farms in Kilifi, Kwale, Machakos and Makueni counties, Kenya in July/August (dry season) and in November/December (wet season), 2019 were conducted to identify scale insect pests (Hemiptera: Coccomorpha) attacking the trees (Sapindales: Rutaceae), and their related biota. A total of 22 scale insect species belonging to four families, namely Diaspididae (armoured scales), Coccidae (soft scales), Pseudococcidae (mealybugs), and Monophlebidae (giant mealybugs) were found infesting citrus trees in the two regions surveyed. Among the scale insects reported, four species were newly introduced in Kenya; three armoured scales Parlatoria ziziphi (Lucas), Parlatoria pergandii (Comstock), Aonidiella comperei (McKenzie), and a soft scale, Pulvinaria polygonata (Cockerell). The scale insects were closely associated with predators (coccinellids and lacewings) and attendant ants. This information will be helpful in the development of efficient management strategies against the scale insect pests, thus improving citrus production in Kenya. The scale insect pests identified in this study will be useful to plant quarantine facilities in Kenya to help to prevent and detect accidental introductions of exotic scale insect species.
\end{abstract}

Keywords: Armored scales, diversity, Kenya, mealybugs, soft scales.

\section{INTRODUCTION}

Scale insects belong to the Order Hemiptera, Suborder Stenorrhyncha, Infraorder Coccomorpha, Superfamily Coccoidea, with about 8,000 described species (Gullan and Cook, 2007; Mansour et al., 2017). Currently, there are 50 known scale insect families; 34 are extant, and 16 are known only from fossils (Kondo et al., 2008; Garcia Morales et al., 2016). They are grouped into different families based on the morphological features of the adult female's cuticle, and sometimes the anatomy of the adult male. The largest and most dominant families arranged according to diversity are the Diaspididae, Pseudococcidae, and Coccidae (Kondo et al., 2008). The body size ranges from 0.1 to $25 \mathrm{~mm}$ long (Gullan and Cook, 2007; Gullan and Martin, 2009; Miller et al., 2014). The biology of scale insects is tremendously diverse; development patterns vary depending on species, environment, and sex. Reproductive methods in scale insects vary among species, from sexual or parthenogenesis, or hermaphroditism (Pellizari and Germain, 2010; Malumphy, 2015).

Extreme sexual dimorphism is exhibited in scale insects; the adult female is relatively large and larviform, neotenic, sessile, and is usually able to feed. In contrast, the small adult male is winged and mobile but lacks mouthparts and cannot feed, which shortens his lifespan to a few hours or days (Kondo et al., 2008; Gullan and Martin, 2009; Mansour et al., 2017). In the female, the eggs hatch into first-instar crawlers; there are usually three immature instars before the larviform adult stage. The male undergoes two feeding nymphal instars before molting to 
a non-feeding pre-pupa, then a non-feeding pupa, and finally to the winged adult male (Kondo et al., 2008).

Scale insect are sap-feeding insects that impair many plants, and diminish yield and marketable value of attacked plants (Martins et al., 2014). On citrus trees, scale insects inflict direct damage by extracting plant sap containing water and nutrients, reducing host-plant vigor and causing wilting, which stops photosynthesis. During feeding, saliva is injected into the plant (Bhagat and Qureshi, 2016), which can be toxic, causing death of the plant tissues. Attack by numerous scale insects results in the development of yellow chlorotic spots, leaf necrosis and premature defoliation, branch dieback, leaf, and stem distortion, reduced new shoot formation, and can result in the death of the affected plant (Kondo et al., 2008; Hassan et al., 2012; Buss and Dale, 2016). After imbibing large volumes of phloem sap, many types of scale insect eliminate surplus sugary fluid as honeydew, which impacts the citrus trees indirectly. Honeydew fouling on nearby surfaces acts as a substrate for fungus growth, which develops into black sooty mould. The sooty mould blocks light and air from reaching the leaves, impeding photosynthesis and causing plant productivity to decrease. The presence of sticky honeydew and black sooty mould lowers the market value of plant produce and ornamental plants (Muniappan et al., 2009; Martins et al., 2014).

Pests and diseases are the major constraints affecting citrus production in Kenya (Kilalo et al,. 2009). Citrus production experienced a significant decline from 129,532 tonnes/ha in 2003 to 1154 tonnes/ha in 2013 in Kenya (Gitahi, 2018), resulting in reduced farm income, food insecurity, and increased unemployment. Scale insects are some of the important pests of citrus in Kenya (Kilalo, 2004; Olubayo et al., 2011). Worldwide, the main scale insect families known to damage citrus are mealybugs (Pseudococcidae), soft scales (Coccidae), and armoured scales (Diaspididae) (Kondo et al., 2008; Mansour et al., 2017). According to García Morales et al. (2016), about $28 \%$ of scale insects found in Kenya have been introduced from other parts of the world, i.e., 66 out of 234 documented species. Low levels of in-country taxonomic expertise and poor documentation of local scale insect faunas in sub-Saharan Africa makes identification of exotic pests found on crops and fruit trees, and during inspections at ports of entry, difficult. The development of sustainable integrated pest management of scale insects requires accurate knowledge and identification of both the pests and the related biota. Therefore, the objective of the survey was to document the diversity of scale insect pests on citrus trees in Kilifi, Kwale, Machakos and Makueni counties (in the main production areas of citrus), Kenya.

\section{MATERIALS AND METHODS}

Surveys were undertaken in the main citrus-producing areas in Kenya; two Coastal counties (Kilifi and Kwale) and two Lower Eastern counties (Machakos and Makueni). The work took place in July-August (dry season) and November-December (wet season), 2019. A total of 328 orchards situated 1 to $5 \mathrm{~km}$ from the main roads were selected and sampled. On each farm, five citrus trees were selected randomly and some parts of the plants (leaves, stems, branches and fruits) were inspected thoroughly for scale insect infestations. Each selected plant was inspected for scale insects, natural enemies, and ant presence on the leaves, branches, stems, and fruits. Samples for identification were collected by cutting infested host-plant parts together with the insects, to avoid damaging the cuticle, and placing them in brown paper bags. The top of the paper bag containing each sample was folded, stapled and then sealed using a masking tape to prevent sample loss.

Each bag was labeled with county name, locality, GPS coordinates, collector's name, host-plant sampled, and collection date. The samples were placed in a cool box to prevent heat damage, then transported to the laboratory at the National Museums of Kenya for sorting and identification. In the laboratory, the scale insects were processed and mounted on slides using the methodology described in Sirisena et al. (2013). The slide-mounted scale specimens were examined using a Zeiss compound microscope with phase contrast illumination at magnifications of $\times 25$ to $\times 800$. Scale insect specimens were identified to species level using unpublished keys (Watson and Ouvrard, Submitted; Watson, In prep.).

\section{Statistical analysis}

The data collected was cleaned before being analyzed for internal validity. It was then coded, categorized, and tabulated. R software version 4.0.2 (R Core Team, 2019) was used to perform statistical analyses. Scale insect abundance data was modelled using generalized linear mixed models (GLMM) as a function of region and season, as the data showed heterogeneity of variance and deviation from normality. R package Ime4 (Bates et al., 2015) was used to conduct analysis where replicates were used as random factor. Several models were formed based on the formula (Variable $\sim$ Region + Season + Region: Season + (1|Replicate: Region), such that terms could be removed or added from the model. The term 'Region' referred to places where sampling was done, whereas 'Season' was when the sampling was conducted. To analyze the count data with a high proportion of zero values, negative binomial regression analysis was selected as an extension of the Poisson distribution. Tukey's post-hoc comparisons were performed at $\alpha=$ 0.05 , where analysis of variance (ANOVA) showed significant main or interactive effects. The Shannon diversity index $\left(\mathrm{H}^{\prime}\right)$ was calculated for scale insects and related biota in each season and region. The Shannon diversity t-test was used to compare statistical differences between regions and seasons. 
Table 1. Scale insect species attacking citrus trees and their distribution in Coastal and Lower Eastern counties, Kenya, in the dry and wet seasons, 2019.

\begin{tabular}{|c|c|c|c|c|c|c|c|}
\hline Family & Scale species name & Common name & Host-plant & KIf & Kle & Mcks & Mni \\
\hline \multirow{9}{*}{ Coccidae } & Ceroplastes floridensis & Florida wax scale & Citrus limon & $x$ & $x$ & $x$ & $\checkmark$ \\
\hline & Ceroplastes stellifer & Stellate scale & Citrus sinensis & $x$ & $\checkmark$ & $x$ & $x$ \\
\hline & Coccus viridis & Coffee green scale & Citrus sinensis & $\checkmark$ & $\checkmark$ & $x$ & $\checkmark$ \\
\hline & Coccus hesperidum & Brown soft scale & Citrus sinensis & $\checkmark$ & $\checkmark$ & $\checkmark$ & $x$ \\
\hline & Eucalymnatus tesselatus & Tessellated scale & Citrus reticulata & $\checkmark$ & $x$ & $x$ & $x$ \\
\hline & Eucalymnatus tesselatus & Tessellated scale & Citrus sinensis & $\checkmark$ & $x$ & $x$ & $x$ \\
\hline & Pulvinaria polygonata & Cottony citrus scale & Citrus sinensis & $\checkmark$ & $\checkmark$ & $x$ & $x$ \\
\hline & Saissetia zanzibarensis & ** & Citrus sinensis & $\checkmark$ & $\checkmark$ & $x$ & $x$ \\
\hline & Udinia farquharsoni & ** & Citrus sinensis & $x$ & $\checkmark$ & $x$ & $x$ \\
\hline \multirow{9}{*}{ Diaspididae } & Aonidiella aurantii & California red scale & Citrus sinensis & $\checkmark$ & $\checkmark$ & $x$ & $\checkmark$ \\
\hline & Aonidiella aurantii & California red scale & Citrus reticulata & $\checkmark$ & $\checkmark$ & $\checkmark$ & $\checkmark$ \\
\hline & Aonidiella aurantii & California red scale & Citrus limon & $\checkmark$ & $\checkmark$ & $\checkmark$ & $x$ \\
\hline & Aonidiella comperei & False yellow scale & Citrus sinensis & $\checkmark$ & $\checkmark$ & $\checkmark$ & $\checkmark$ \\
\hline & Chrysomphalus aonidum & Circular purple scale & Citrus sinensis & $\checkmark$ & $\checkmark$ & $\checkmark$ & $x$ \\
\hline & Fiorinia proboscidaria & ** & Citrus sinensis & $\checkmark$ & $\checkmark$ & $x$ & $x$ \\
\hline & Lepidosaphes beckii & Citrus mussel scale & Citrus sinensis & $x$ & $\checkmark$ & $\checkmark$ & $\checkmark$ \\
\hline & Parlatoria pergandii & Chaff scale & Citrus limon & $x$ & $\checkmark$ & $x$ & $x$ \\
\hline & Parlatoria ziziphi & Black parlatoria scale & Citrus sinensis & $\checkmark$ & $\checkmark$ & $\checkmark$ & $x$ \\
\hline \multirow{2}{*}{ Monophlebidae } & Icerya purchasi & Cottony cushion scale & Citrus sinensis & $\checkmark$ & $\checkmark$ & $\checkmark$ & $\checkmark$ \\
\hline & Icerya seychellarum & Seychelles scale & Citrus sinensis & $x$ & $\checkmark$ & $\checkmark$ & $\checkmark$ \\
\hline \multirow{8}{*}{ Pseudococcidae } & Crisicoccus longipilosus & Long-tailed mealybug & Citrus sinensis & $\checkmark$ & $\checkmark$ & $x$ & $x$ \\
\hline & Crisicoccus longipilosus & Long-tailed mealybug & Citrus limon & $\checkmark$ & $\checkmark$ & $x$ & $x$ \\
\hline & Nipaecoccus viridis & Spherical mealybug & Citrus sinensis & $x$ & $\checkmark$ & $x$ & $x$ \\
\hline & Paracoccus marginatus & Papaya mealybug & Citrus sinensis & $x$ & $x$ & $\checkmark$ & $x$ \\
\hline & Planococcus kenyae & Coffee mealybug & Citrus sinensis & $\checkmark$ & $\checkmark$ & $x$ & $x$ \\
\hline & Pseudococcus cryptus & Citriculus mealybug & Citrus sinensis & $\checkmark$ & $\checkmark$ & $x$ & $\checkmark$ \\
\hline & Pseudococcus cryptus & Citriculus mealybug & Citrus reticulata & $\checkmark$ & $\checkmark$ & $x$ & $\checkmark$ \\
\hline & Pseudococcus cryptus & Citriculus mealybug & Citrus limon & $\checkmark$ & $\checkmark$ & $x$ & $\checkmark$ \\
\hline
\end{tabular}

** = Scale insect species with no common name; ü= Present, $\hat{u}=$ Absent

Key to counties: Mcks $=$ Machakos, $\mathrm{Mni}=$ Makueni, Klf $=$ Kilifi, Kle $=$ Kwale.

\section{RESULTS}

Twenty two scale insect species were found infesting citrus trees in the two regions surveyed (Table 1). The scale insect pests belonged to four families: Coccidae (soft scales), Diaspididae (armoured scale insects), Monophlebidae (giant mealybugs), and Pseudococcidae (true mealybugs). Eight species of Coccidae were found attacking the citrus trees, followed by seven Diaspididae and five Pseudococcidae, distributed in both regions and seasons (Table 1). The Diaspididae species on citrus trees were found in all four counties in both seasons. The Monophlebidae on citrus trees were represented by only two species, distributed in all four counties in both seasons (Table 1). In the Coastal counties (Kilifi and Kwale), all the scale insect species attacking citrus trees were reported except for two: papaya mealybug (Paracoccus marginatus Williams and Granara de Willink) and Florida wax scale (Ceroplastes floridensis Comstock), which were only found in the Lower Eastern counties (Machakos and Makueni) on lemon (Citrus limon) and orange (Citrus sinensis), respectively (Table 1 ).

The abundance of scale insects was affected by different regions (Table 2); for instance, the average number of Aonidiella comperei was five times more in the Coastal region (2.5 individuals per plant) compared to the Lower Eastern region ( 0.5 individuals per plant). The trend was also similar in Aonidiella aurantii, Parlatoria ziziphi and Pseudococcus cryptus, with 35.3, 13.6 and 4.4 individuals per plant in the Coastal region and 34.2, 1.6, and 0.8 
Table 2. Scale insect abundance (average number of individuals $\pm S E$ ) influenced by region $(n=3)$.

\begin{tabular}{|c|c|c|c|c|c|c|c|c|c|c|}
\hline \multirow{2}{*}{\multicolumn{2}{|c|}{ Scale insect description }} & \multicolumn{6}{|c|}{ Region } & \multirow{2}{*}{\multicolumn{3}{|c|}{ p-values }} \\
\hline & & \multicolumn{3}{|c|}{ Coastal (Seasons) } & \multicolumn{3}{|c|}{ Lower eastern (Seasons) } & & & \\
\hline Family & Genera/species & Dry & Wet & Mean & Dry & Wet & Mean & Region & Season & $\mathbf{R}^{\star} \mathbf{S}$ \\
\hline \multirow{7}{*}{ Diaspididae } & Aonidiella comperei & $1.4 \pm 1.4^{\mathrm{a}}$ & $3.6 \pm 1.6^{a}$ & $2.5 \pm 1.5^{A}$ & $1.1 \pm 1.1^{\mathrm{a}}$ & $0.0^{\mathrm{a}}$ & $0.4 \pm 0.3^{B}$ & $<0.001$ & 0.628 & 1.000 \\
\hline & Aonidiella aurantii & $0.0^{\mathrm{a}}$ & $0.4 \pm 0.4^{\mathrm{a}}$ & $35.3 \pm 0.6^{A}$ & $30.8 \pm 9.5^{\mathrm{a}}$ & $38.4 \pm 18.8^{a}$ & $34.2 \pm 15.5^{\mathrm{B}}$ & $<0.001$ & 0.027 & 1.000 \\
\hline & Chrysomphalus aonidum & $9.1 \pm 5.0^{\mathrm{a}}$ & $5.1 \pm 2.4^{\mathrm{a}}$ & $7.1 \pm 3.9^{A}$ & $5.2 \pm 4.9^{a}$ & $3.0 \pm 2.7^{\mathrm{a}}$ & $3.9 \pm 3.8^{\mathrm{A}}$ & $<0.001$ & $<0.001$ & 1.000 \\
\hline & Fiorinia proboscidaria & $2.3 \pm 2.3^{a}$ & $0.7 \pm 0.7^{a}$ & $1.4 \pm 1.2^{\mathrm{A}}$ & $0.0^{\mathrm{a}}$ & $0.0^{\mathrm{a}}$ & $0.0^{\mathrm{A}}$ & $<0.001$ & $<0.001$ & 1.000 \\
\hline & Lepidosaphes beckii & $5.4 \pm 3.8^{\mathrm{a}}$ & $9.8 \pm 3.8^{a}$ & $13.2 \pm 3.8^{A}$ & $8.8 \pm 3.5^{a}$ & $16.3 \pm 12.5^{a}$ & $7.7 \pm 6.9^{A}$ & 1.000 & 1.000 & $<0.001$ \\
\hline & Parlatoria ziziphi & $17.0 \pm 10.8^{a}$ & $10.3 \pm 3.1^{\mathrm{a}}$ & $13.6 \pm 7.9^{A}$ & $3.8 \pm 2.6^{a}$ & $0.0^{\mathrm{b}}$ & $1.6^{\mathrm{B}}(1.7)$ & $<0.001$ & 0.307 & 1.000 \\
\hline & Parlatoria pergandii & $0.6^{\mathrm{a}} 0.6^{\mathrm{a}}$ & $0.0^{\mathrm{a}}$ & $0.3 \pm 0.3^{\mathrm{A}}$ & $0.0^{\mathrm{a}}$ & $0.0^{\mathrm{a}}$ & $0.0^{\mathrm{A}}$ & $<0.001$ & 1.000 & 1.000 \\
\hline \multirow{7}{*}{ Coccidae } & Ceroplastes floridensis & $0.0^{\mathrm{a}}$ & $0.0^{\mathrm{a}}$ & $0.0^{\mathrm{A}}$ & $0.6 \pm 0.6^{a}$ & $0.0^{\mathrm{a}}$ & $0.2 \pm 0.2^{\mathrm{A}}$ & $<0.001$ & 1.000 & 1.000 \\
\hline & Ceroplastes stellifer & $0.4 \pm 0.4^{a}$ & $0.1 \pm 0.1^{\mathrm{a}}$ & $0.2 \pm 0.2^{\mathrm{A}}$ & $0.0^{\mathrm{a}}$ & $0.0^{\mathrm{a}}$ & $0.0^{\mathrm{A}}$ & $<0.001$ & 0.006 & 1.000 \\
\hline & Coccus viridis & $2.6 \pm 2.2^{\mathrm{a}}$ & $7.6 \pm 3.6^{a}$ & $5.1 \pm 3.0^{\mathrm{A}}$ & $10.1 \pm 5.8^{b}$ & $122.3 \pm 26.6^{a}$ & $76.2 \pm 24.6^{A}$ & $<0.001$ & 0.013 & 0.227 \\
\hline & Coccus hesperidum & $6.9 \pm 3.5^{\mathrm{a}}$ & $4.4 \pm 2.7^{a}$ & $5.7 \pm 3.1^{\mathrm{A}}$ & $0.0^{\mathrm{a}}$ & $7.4 \pm 11.6^{\mathrm{a}}$ & $4.4 \pm 3.9^{\mathrm{A}}$ & 1.000 & $<0.001$ & 1.000 \\
\hline & Eucalymnatus tesselatus & $0.0^{\mathrm{a}}$ & $0.9 \pm 1.4^{\mathrm{a}}$ & $0.5 \pm 0.5^{A}$ & $0.0^{\mathrm{a}}$ & $0.0^{\mathrm{a}}$ & $0.0^{\mathrm{A}}$ & 1.000 & $<0.001$ & 1.000 \\
\hline & Saissetia zanzibarensis & $1.3 \pm 1.6^{\mathrm{a}}$ & $1.0 \pm 0.3^{\mathrm{a}}$ & $1.1 \pm 1.4^{\mathrm{A}}$ & $0.0^{\mathrm{a}}$ & $0.0^{\mathrm{a}}$ & $0.0^{\mathrm{A}}$ & $<0.001$ & 0.188 & 1.000 \\
\hline & Udinia farquharsoni & $0.0^{\mathrm{a}}$ & $0.6 \pm 0.3^{a}$ & $0.3 \pm 0.1^{\mathrm{A}}$ & $0.0^{\mathrm{a}}$ & $0.0^{\mathrm{a}}$ & $0.0^{A}$ & $<0.001$ & 0.167 & 1.000 \\
\hline \multirow{5}{*}{ Pseudococcidae } & Nipaecoccus viridis & $0.7 \pm 0.7^{a}$ & $0.3 \pm 0.3^{a}$ & $0.5 \pm 0.5^{\mathrm{A}}$ & $0.0^{\mathrm{a}}$ & $0.0^{\mathrm{a}}$ & $0.0^{\mathrm{A}}$ & $<0.001$ & 0.002 & 1.000 \\
\hline & Paracoccus marginatus & $0.0^{\mathrm{a}}$ & $0.0^{\mathrm{a}}$ & $0.0^{\mathrm{A}}$ & $0.7 \pm 0.7^{a}$ & $0.0^{\mathrm{a}}$ & $0.3 \pm 0.3^{A}$ & 1.000 & 0.002 & 1.000 \\
\hline & Planococcus kenyae & $0.5 \pm 0.5^{a}$ & $0.9 \pm 0.9^{a}$ & $0.7 \pm 0.7^{\mathrm{A}}$ & $0.0^{\mathrm{a}}$ & $0.0^{\mathrm{a}}$ & $0.0^{\mathrm{A}}$ & $<0.001$ & 0.742 & 1.000 \\
\hline & Pseudococcus cryptus & $3.4 \pm 2.4^{\mathrm{a}}$ & $5.4 \pm 2.3^{a}$ & $4.4 \pm 2.3^{A}$ & $0.0^{\mathrm{a}}$ & $1.3 \pm 1.3^{a}$ & $0.8 \pm 0.6^{B}$ & $<0.001$ & 0.230 & 1.000 \\
\hline & Crisicoccus longipilosus & $0.0^{\mathrm{a}}$ & $1.4 \pm 1.4^{\mathrm{a}}$ & $0.7 \pm 1.1^{\mathrm{A}}$ & $0.0^{\mathrm{a}}$ & 0.0 & $0.0^{\mathrm{A}}$ & $<0.001$ & 0.001 & 1.000 \\
\hline \multirow{2}{*}{ Monophlebidae } & Icerya purchasi & $0.1 \pm 0.1^{\mathrm{a}}$ & $0.7 \pm 0.7^{a}$ & $0.4 \pm 0.4^{\mathrm{A}}$ & $0.9 \pm 0.9^{a}$ & $0.0^{\mathrm{b}}$ & $0.4 \pm 0.4^{\mathrm{A}}$ & 1.000 & 0.464 & $<0.001$ \\
\hline & Icerya seychellarum & $0.1 \pm 0.1^{b}$ & $1.1 \pm 0.7^{a}$ & $0.6 \pm 0.5^{A}$ & $3.3 \pm 2.2^{\mathrm{a}}$ & $2.0 \pm 2.0^{\mathrm{a}}$ & $2.5 \pm 2.2^{A}$ & $<0.001$ & 0.307 & 0.139 \\
\hline$S$ & & 15 & 18 & & 9 & 7 & & & & \\
\hline$H^{\prime}$ & & 1.9 & 2.4 & & 1.6 & 1.1 & & & & \\
\hline
\end{tabular}

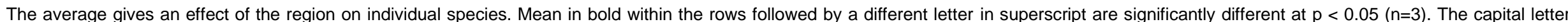

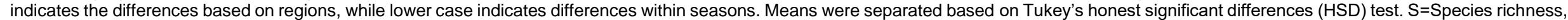
$H^{\prime}=$ Shannon diversity index, $R^{*} S=$ Interaction between regions and seasons.

individuals per plant in the Lower Eastern region, respectively (Table 2). In the Lower Eastern region, Coccus viridis had a species abundance (76.2 individuals per plant), 15 times higher than its average in the Coastal region (5.1 individuals per plant). Similarly, Icerya seychellarum (Westwood) abundance was four times higher in the Lower Eastern region ( 2.5 individuals per plant) compared to the Coastal region ( 0.5 individuals per plant). In the Coastal region, $I$. seychellarum abundance showed significant differences between seasons; 1.1 individuals per plant in the wet season but only 
0.1 individuals per plant in the dry season. In contrast, Parlatoria ziziphi in the Lower Eastern region had 3.8 individuals per plant during the dry season compared to 0.0 individuals per plant in the wet season. The abundance of this species showed significant differences in the Coastal region also, where it was five times higher in the wet season ( 0.5 individuals per plant) compared to the dry season ( 0.1 individuals per plant) (Table 2 ).

The Shannon diversity t-test revealed a statistical difference in diversity between regions during the dry season (Shannon t-test $=10.3$; d.f $=4455 ; \mathrm{p}<0.001$ ) whereas there was no statistical difference during the wet season (Shannon t-test $=66.6$; $d . f=7347 ; p=0$ ).

Also, the species richness was higher in the Coastal region during the wet season (18 species) compared to dry season (15 species). In the Lower Eastern region, the species richness was higher during the dry season (9 species) compared to 7 species during the wet season.

\section{DISCUSSION}

From the findings, citrus trees in the Coastal (Kilifi and Kwale) and Lower Eastern counties, (Machakos and Makueni) were infested by scale insects. The same pest species also have been reported to be serious citrus pests in other studies conducted in Kenya (Kilalo, 2004, Olubayo et al., 2011; Gitahi, 2018). Twenty two scale insect species were found infesting citrus trees in the two regions. Soft scales (Coccidae) had a total of eight species; armoured scales (Diaspididae) were the second most speciose family, with a total of seven species attacking various citrus varieties; mealybugs (Pseudococcidae) had five species, while giant mealybugs (Monophlebidae) had two species attacking different citrus varieties. This differs from the statements of Gullan and Cook (2007), Kondo et al. (2008), Gullan and Martins (2009), Seljak (2010) and García Morales et al. (2016) that Diaspididae is the most biodiverse family followed by mealybugs and then soft scales. Aonidiella aurantii, Chrysomphalus aonidum and Lepidosaphes beckii were the main diaspidids attacking citrus trees in the two regions studied. The same species have been recorded as important citrus pests elsewhere (Tawfeek, 2012; Seljak, 2010; Ouvrard et al., 2013 Dagnew et al., 2014; Uygun and Satar, 2017). Most of the armoured scale species recorded attacking citrus were found in the Coastal region. This could be due to the high humidity and temperatures there, helping the pests to thrive (Camacho and Chong, 2015; Heya et al., 2020). Three diaspidid species on citrus were found to be introduced species in Kenya: Aonidiella comperei, Parlatoria pergandii and P. ziziphi. This concurs with the other finding that most armoured scale insect pests are invasive, introduced species due to their small size and cryptic habits (Pellizari and Germain, 2010). These pest species are important citrus pests in other countries too (Tawfeek, 2012; Taibi et al., 2016).
Soft scales (Coccidae) were the most speciose family found during the study. This contrasts with findings in other countries where the armoured scales are most speciose species on trees (Gullan and Cook, 2007; Kondo et al., 2008; Ouvrard et al., 2013; García Morales et al., 2016). This might be due to the fact that the scale insect sampling on citrus plants was done in only 4 counties of Kenya. With the exception of Ceroplastes floridensis, all the other soft scales recorded in this study were found mostly in the Coastal region. This could be attributed to high temperatures and humidity in the region providing favorable conditions for them to thrive (Camacho and Chong, 2015; Heya, 2020); in addition, there are numerous ports of entry found in the region. One species of Coccidae was found to be new to Kenya; Pulvinaria polygonata Cockerell, which is a serious agricultural pest throughout the tropics (Mani and Krishnamoorthy, 1998). There is a need to monitor this species in future to avoid potential catastrophic devastation of the citrus industry in the region. Coccus viridis and $C$. hesperidum previously have been recorded as serious citrus pests in Kenya (Kilalo, 2004, Olubayo et al., 2011, Gitahi, 2018). Soft scales, often being polyphagous, have been reported to be serious pests of other crops worldwide such as grape, mango and papaya (Kapranas et al., 2007; Walton et al., 2009; Martins et al., 2014).

All the five mealybugs recorded in this study have been recorded in Kenya attacking the citrus before (García Morales et al., 2016, Macharia et al., 2017) and have been recorded elsewhere attacking citrus trees (Franco et al., 2004). Most of the mealybugs were found in the Coastal counties, attacking various citrus varieties. This finding is similar to that of Heya (2020) that indicated that the Coastal region was a hotspot for mealybug invasion, followed by Lower Eastern counties and the Central region. Their occurrence in the Coastal region could be attributed to high humidity and temperature which suit the pests (Camacho and Chong, 2015; Heya, 2020). Being polyphagous, these pests are known to attack a wide host range. The papaya mealybug, Paracoccus marginatus, is an introduced, invasive species and polyphagous; it was first reported in Kenya in 2017 in the Coastal region attacking papaya resulting to $91 \%$ crop loss (Carica papaya) (Macharia et al., 2017) and has been reported to attack citrus (Mastoi et al., 2011; Heya, 2020); it was also found to attack citrus in this study. Two monophlebids were also recorded attacking citrus trees in both regions. Although it was found at a low frequency in this study, Icerya purchasi can be a serious citrus pest. It was recorded in the Coastal region as well as in the Lower Eastern region in all four counties studied, attacking only sweet orange (Citrus sinensis). The species is of great economic importance elsewhere (Walton et al., 2009; Seljak, 2010; Jendoubi, 2018; Gebreslasie and Meresa, 2018).

The Coastal and Lower Eastern regions affected the abundance of some of the scale insects that showed a 
varying trend. This could have been due to the climatic conditions in the Coastal region suiting the development and multiplication of some scale insect species (Camacho and Chong, 2015; Heya, 2020) more than others. The abundance of Aonidiella aurantia, $A$. comperei and Pseudococcus cryptus was highest in the Coastal region $(\mathrm{p}<0.001)$, while that of Coccus viridis and Icerya seychellarum was higher in the Lower Eastern region than at the Coast $(p<0.001)$. The excessive use of pesticides in the two regions to control citrus pests could also have affected the abundance of scale insects.

Scale insect diversity and richness also showed a varying trend in the four counties between the two seasons. Being a lowland, the high temperatures and humidity in the Coastal region could be the main factor causing variation in scale insect abundance between regions and seasons (Camacho and Chong, 2015). Additionally, with the Coastal region having important international entry points, more pests may be present in the area due to international trade and inadequate quarantine services at the ports of entry. Flush growth of citrus trees probably accounts for the scale insect increment during the wet season in these regions.

The study provided information that is useful in understanding the biodiversity of scale insects in the two regions. It will also be used in plant quarantine facilities in Kenya for identification of pests which aids in preventing introduction of new pests in the country.

\section{ACKNOWLEDGEMENTS}

We wish to thank the United Kingdom's Darwin Initiative scheme project 25-032 through the Natural History Museum, U.K., for financial support of Michael Githae's M.Sc. study under the Project, "Agriculture and biodiversity: Addressing scale insect threats in Kenya". Further, we thank the project partners KEPHIS, NMK, UON, CABI and NHM-UK for information provided during the project. We appreciate and thank the County Governments of Kilifi, Kwale, Machakos and Makueni and the farmers for permitting access to the study sites. Special thanks are due to National Museums of Kenya and University of Nairobi for providing research facilities and equipment; and to Josiah Achieng (technician, National Museums of Kenya, Nairobi, Kenya) for guidance and assistance in the identification of scale insects.

\section{CONFLICT OF INTEREST}

The authors declare that they have no conflict of interest.

\section{REFERENCES}

Bates, D., Mächler, M., Bolker, B., \& Walker, S. (2015). Fitting linear mixed-effects models using Ime4. Journal of Statistical Software, 67(1), 1-48.
Bhagat, R. C., \& Qureshi, A. A. (2016). Biodiversity and annotated checklist of scale-insects, and Mealybugs (Hemiptera: Coccoidea) of Jammu, Kashmir and Ladakh (North-west Himalaya), India. International Journal of Current Research and Academic Review, 4(3), 56-62.

Buss, E. A., \& Dale, A. (2016). Managing scale insects on ornamental plants 1. University of Florida, IFAS Extension, ENY323. Pp. 1-6. Retrieved 7th December 2020 from https://edis.ifas.ufl.edu/pdffiles/MG/MG00500.pdf.

Camacho, E. R., \& Chong, J. H. (2015). General biology and current management approaches of soft scale pests (Hemiptera: Coccidae). Journal of Integrated Pest Management, 6(1), 1-22.

Dagnew, A., Belew, D., Admassu, B., \& Yesuf, M. (2014). Citrus production, constraints and management practices in Ethiopia: The case of Pseudocercospora leaf and fruit spot disease. Science, Technology and Arts Research Journal, 3(2), 4-18.

Franco, J. C., Suma, P., Da Silva, E. B., Blumberg, D., \& Mendel, Z. (2004). Management strategies of mealybug pests of citrus in Mediterranean countries', Phytoparasitica, 32(5), 507-522.

García Morales, M., Denno, B. D., Miller, D. R., Miller, G. L., BenDov, Y., \& Hardy, N. B. (2016). ScaleNet: A literature-based model of scale insect biology and systematics. Database: The Journal of Biological Databases Curation, Vol. 2016, Article ID bav118, Pp. 1-5. Retrieved 7th December 2020 from https://academic.oup.com/database/article/doi/10.1093/datab ase/bav118/2630093.

Gebreslasie, A., \& Meresa, H. (2018). Identification of insect and disease associated to citrus in Northern Ethiopia. African Journal of Microbiology Research, 12(13), 312-320.

Gitahi, D. W. (2018). Evaluation of knowledge and practices of managing citrus pests and diseases and the willingness to pay for an integrated pest management strategy in selected Counties in Kenya (Doctoral dissertation, Egerton University).

Gullan, P. J., \& Cook, L. G. (2007). Phylogeny and higher classification of the scale insects (Hemiptera: Sternorrhyncha: Coccoidea). Zootaxa, 1668, 413-425.

Gullan, P. J., \& Martin, J. H. (2009). Sternorrhyncha (jumping plant-lice, whiteflies, aphids, and scale insects). In: Encyclopedia of insects (pp. 957-967). Academic Press.

Hassan, N. A., Radwan, S. G., \& El-Sahn, O. M. N. 2012. Common scale insects (Hemiptera: Coccoidea) in Egypt. Egyptian Academic Journal of Biological Science, 5(3), 153160.

Heya, H. M., Khamis, F. M., Onyambu, G. K., Akutse, K. S., Mohamed, S. A., Kimathi, E. K., Ombura, F. L. O., Ekesi, S., Dubois, T., Subramanian, S., \& Tanga, C. M. (2020). Characterization and risk assessment of the invasive papaya mealybug, Paracoccus marginatus, in Kenya under changing climate. Journal of Applied Entomology, 144(6), 442-458.

Jendoubi, H. (2018). The scale insect fauna of citrus in Tunisia: a critical overview. International Journal of Fauna and Biological Studies, 5(3), 169-178.

Kapranas, A., Morse, J. G., Pacheco, P., Forster, L. D. \& Luck, R. F. (2007). Survey of brown soft scale Coccus hesperidum L. parasitoids in southern California citrus. Biological Control, 42(3), 288-299.

Kilalo, D. C. (2004). Survey of the arthropod complex and monitoring and management of homopteran pests of citrus (Citrus spp) and their natural enemies (Doctoral dissertation, University of Nairobi).

Kilalo, D., Olubayo, F., Obukosia, S., \& Shibairo, S. I. (2009). Farmer management practices of citrus insect pests in Kenya. African Journal of Horticultural Science, 2,168-176. 
Kondo, T., Gullan, P. J., \& Williams, D. J. (2008). Coccidology. The study of scale insects (Hemiptera: Sternorrhyncha: Coccoidea). Revista Corpoica - Ciencia y Tecnología Agropecuaria, 9(2), 55-61.

Macharia, I., Kimani, E., Koome, F., Kosiom, T., Heya, H., Otipa, M., \& Oronje, M. (2017). First report and distribution of the Papaya Mealybug, Paracoccus marginatus, in Kenya. Journal of Agricultural and Urban Entomology, 33(1), 142-151.

Malumphy, C. (2015). Detection and identification of scale insects families. The Food and Environment Agency (U.K.), Fera 2015-v1, pp.1-23.

Mani, M., \& Krishnamoorthy, A. (1998). Biological control studies on the mango green shield scale Chloropulvinaria polygonata (Ckll.) (Homoptera, Coccidae) in India. Entomon, 23(2), 105110.

Mansour, R., Grissa-Lebdi, K., Suma, P., Mazzeo, G. \& Russo, A. (2017). Key scale insects (Hemiptera: Coccoidea) of high economic importance in a Mediterranean area: host-plants, bio-ecological characteristics, natural enemies and pest management strategies-a review. Plant Protection Science, 53(1), 1-14.

Martins, D. S., Fornazier, M. J., Culik, M. P., Ventura, J. A., Ferreira, P. S. F., \& Zanuncio, J. C. (2014). Scale insect (Hemiptera: Coccoidea) pests of papaya (Carica papaya) in Brazil. Annals of the Entomological Society of America, 108(1), 35-42.

Mastoi, M. I., Azura, A. N., Muhammad, R., Idris, A. B. \& Ibrahim, Y. (2011). First report of papaya mealybug Paracoccus marginatus (Hemiptera: Pseudococcidae) from Malaysia. Australian Journal of Basic and Applied Sciences, 5(7), 12471250.

Miller, D., Rung, A., Parikh, G., Venable, G., Redford, A. J., Evans, G. A., \& Gill, R. J. (2014). Scale Insects, Edition 2. USDA APHIS Identification Technology Program (ITP), Fort Collins, Colorado, U.S.A. Retrieved 7th December 2020 from http://idtools.org/id/scales/index.php.

Muniappan, R., Shepard, B. M., Watson, G. W., Carner, G. R., Sartiami, D., Rauf, A. \& Hammig, M. D. (2008). First report of the Papaya Mealybug, Paracoccus marginatus (Hemiptera: Pseudococcidae), in Indonesia and India. Journal of Agricultural and Urban Entomology, 25(1), 37-40.

Olubayo, F., Kilalo, D., Obukosia, S., Shibairo, S., Kasina, M, Kasina, A. M., \& Kasina, M. (2011). Homopteran Pests Complex Of Citrus (Citrus sinensis). International Journal of Sustainable Crop Production, 6(2), pp. 23-28.
Ouvrard, D., Kondo, T., \& Gullan, P. J. (2013). Scale insects: Major pests and management. Encyclopedia of Pest Management, 1-4.

Pellizzari, G., Germain, J-F. (2010). Scales (Hemiptera, Superfamily Coccoidea). Chapter 9.3. BioRisk, 4(1), 475-510.

$\mathrm{R}$ Core Team (2019). A language and environment for statistical computing. Vienna, Austria: R Foundation for Statistical Computing; 2012. Received 7th December, 2020 from https://www.R-project.org.

Seljak, G. (2010). A checklist of scale insects of Slovenia. Entomologia Hellenica, 19(2), 99-113.

Sirisena, U. G. A. I., Watson, G. W., Hemachandra, K. S., \& Wijayagunasekara, H. N. P. (2013). A modified technique for the preparation of specimens of Sternorryncha for taxonomic studies. Tropical Agricultural Research, 24(2),139-149.

Taibi, A., Gacemi, A., Medjdoub, Y., Medjdoub, I., \& Doumandji, S. (2016). Citrus infestation by the black scale, Parlatoria ziziphi Lucas (Homoptera: Diaspididae) in Tlemcen, Algeria. Journal of Entomological Research, 40(3), 217-221.

Tawfeek, M. E. (2012). Distributions of armoured scale insects infesting citrus trees in different localities in Egypt. Journal of Entomology, 9(6), 429-434.

Uygun, N., \& Satar, S. (2008). The current situation of citrus pests and their control methods in Turkey. IOBC-WPRS Bulletin, 38, 2-9.

Walton, V. M., Krüger, K., Saccaggi, D. L., Millar, I. M., \& Michaud, J. P. (2009). A survey of scale insects (Sternorrhyncha: Coccoidea) occurring on table grapes in South Africa. Journal of Insect Science, 9(47), 1-6.

Watson, G. W. (In prep.) Towards identification of the scale insects (Hemiptera: Coccomorpha) of continental Africa: 2-7. Zootaxa (unpublished).

Watson, G. W., \& Ouvrard, D. (Submitted) Towards identification of the scale insects (Hemiptera: Coccomorpha) of continental Africa: 1. Identification of the families currently known. Zootaxa (unpublished). 